\title{
Makt, kritik och subjektivering: En essä om Foucault och bildningens aktualitet
}

\section{Av Roddy Nilsson}

I

Michel Foucault var en av 1900-talets mest inflytelserika samhällsteoretiker. Genom hans författarskap har samhällsvetenskapen och humaniora begåvats med en rad nya teoretiska ansatser, begrepp och problematiseringar. ${ }^{1}$ Däremot har Foucault sällan, åtminstone inte i vårt land, varit en referenspunkt eller inspirationskälla i diskussionen kring bildning och bildningstraditioner. ${ }^{2}$ Snarare har han utpekats som en av dem som setts som en del i den process som har undergrävt tron på bildningens plats i vår tid. Tillsammans med andra företrädesvis franska tänkare som Derrida, Lyotard, Deleuze och Baudrillard har han setts företräda en farlig och improduktiv antihumanism, relativism, irrationalism och vetenskapsfientlighet och en fixering vid makt, vilket sammantaget skulle ha lett till att sanning och moral och andra klassiska bildningsvärden underminerats. ${ }^{3}$ De nyss nämnda tänkarna har fungerat som centrala inspirationskällor i de senaste decenniernas postmoderna och postkoloniala teoribildningar där den traditionella bildningen ofta hållits för att vara ett uttryck för maktutövning och för västerländsk dominans och eurocentrism. ${ }^{4}$ Det mest välkända exemplet inom denna genre är förmodligen Edwards Saids tydligt Foucaultinspirerade arbete Orientalism. ${ }^{5}$ Det finns dock många sätt att förstå och använda Foucaults texter. Jag ska i denna korta artikel försöka ge en bild av Foucaults tänkande som möjligt att inkludera i en diskussion som betonar bildningens betydelse. ${ }^{6}$ Först dock några korta reflektioner kring bildningens villkor och funktioner i dagens samhälle.

I den västerländska traditionen har det ofta betonats hur bildning, i kontrast till en snäv, specialiserad professionskunskap, varit avsedd att fungera som en fördjupad kultivering av hela människan. I bildningsbegreppets klassiska betydelse av ty. Bildung, men också i dess amerikanska variant i form av liberal education, pekar detta mot en lärprocess som utvecklar personligheten och stärker identiteten. Genom att bli en del av denna process tänks individen på något sätt gå utöver sig själv och utveckla sin potential. Vissa formella och synbara kriterier för bildning brukar också framhållas. Bland dessa återfinns högre examina, läsning av goda böcker, förmåga att uttrycka sig väl i tal och skrift och ibland också någon form av "förfinat" och civiliserat beteende. Inom bildningstradi-

1 För en introduktion till Foucaults tänkande se Nilsson 2008.

2 Bland undantagen se Uljens 2007 där författaren utifrån pedagogisk synvinkel diskuterar bildning och kritik med utgångspunkt i Foucaults tänkande.

3 Nordin 2008.

4 Jonsson 2007.

5 Said 1993.

6 För ett Foucaultinspirerat synsätt på bildningsbegreppets historia och kluvenhet, i synnerhet inom den liberala traditionen, se Kaveh 2012. 
tionen har det funnits en grundläggande tanke om bildningen som frigörande, som något på vars grund en självständig och i utveckling varande individ kan formas. Samtidigt har bildningsgången innehållit ett element av osäkerhet genom att man inte på förhand har kunnat veta vad den kan leda till. ${ }^{7}$ Tanken om bildningens frigörande potential har dock ofta i praktiken samsats med ett nödvändigt element av självdisciplinering i så måtto att vara bildad också kräver ett visst mått av anpassning och inordning i befintliga traditioner. $^{8}$

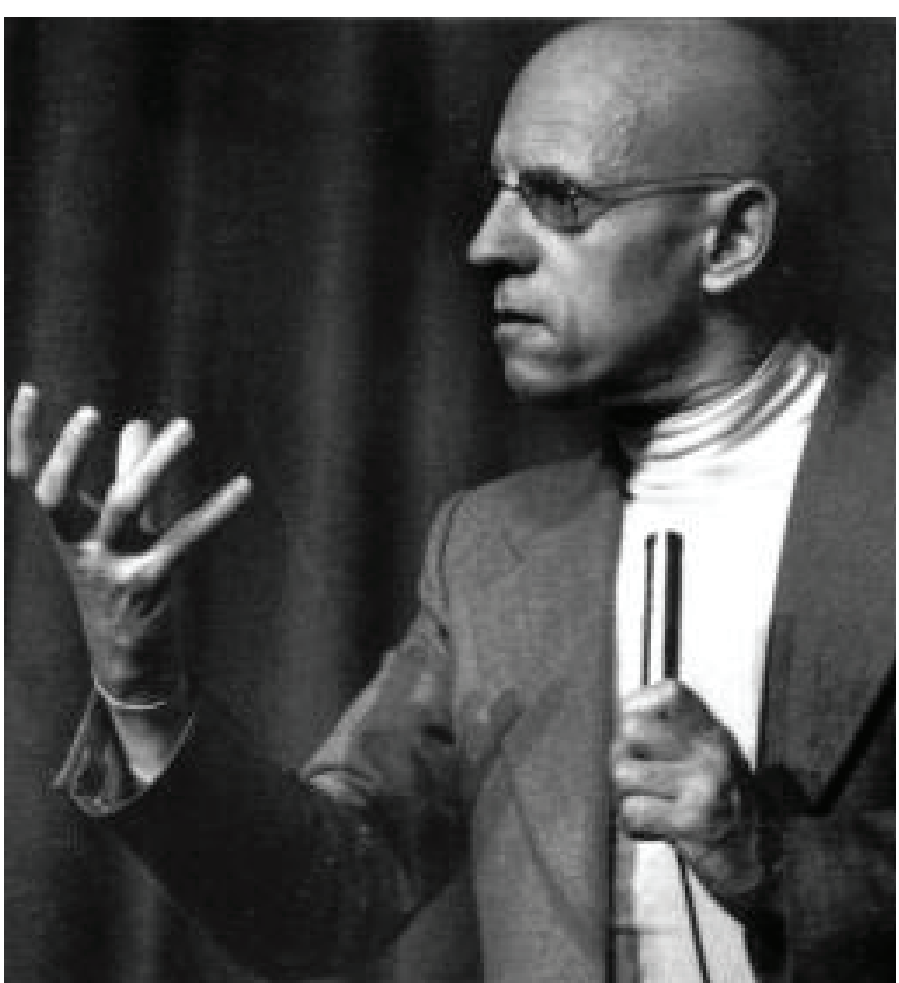

Debattören Michel Foucault. Fransk tv, 1966.

De flesta bildningsförespråkare har också betonat hur företeelsen kunnat spela rollen av en motvikt mot ett ensidigt och instrumentellt nyttotänkande. ${ }^{9}$ Det har hos många av detta nyttotänkandes förespråkare, inte minst under 1900-talets senare del, funnits en tydlig tendens att se bildning som något förknippad med ett äldre samhälle och med kunskaper och kompetenser som inte längre är gångbara. ${ }^{10}$ Svensk Näringslivs uppmärksammade kampanj med varningsord till de studenter som avsåg att slösa bort sin dyrbara studietid på vad som beskrevs som "hobbykurser" inom områden som humaniora och konst - i stället för att satsa på nyttiga och tillväxtbefrämjande yrkesutbildningar - kan i detta sammanhang ses som det senaste uttrycket för denna tendens. ${ }^{11}$ Svenskt Näringslivs hållning kan därmed ses som ett uttryck för en motströmning som tagit sig många former och som funnits i princip lika länge som själva bildningstanken. Ett exempel är 1800-talets motsättning mellan å ena sidan latinförespråkare och nyhumanister och å andra de som förordade en utbildning med inriktning mot naturvetenskap, ekonomi och moderna språk, ett annat spänningen inom 1900-talets socialdemokrati mellan å ena sidan bildningsidealister och folkbildare och å andra bejakare av teknik och social ingenjörskonst. ${ }^{12}$

Samtidigt har under de senaste åren en förnyad problematisering av bildningen skett vilket lett till att dess betydelse och plats i vårt (post)moderna samhälle har diskuterats

\footnotetext{
7 Broady 2012, s 285.

8 Burman \& Sundgren 2010, s 12.

9 Burman \& Sundgren 2010, s 11.

10 Burman \& Sundgren 2010, s $22 \mathrm{ff}$.

11 Fölster, Kreicsbergs \& Sahlén 2011.

12 Se t ex i det förstnämnda fallet Niléhn 1975 och det senare Björk 2008.
} 
inom ramen för en mer öppen och mångtydig förståelse. ${ }^{13}$ I flera antologier och debattskrifter har bildningsbegreppet och dess olika avledningar blivit föremål för intressanta och kreativa nyläsningar där såväl dess historia som dess betydelse och innebörd i samtiden har diskuterats. ${ }^{14}$ I detta sammanhang har det rent av talats om en form av renässans för bildningsidealen. ${ }^{15}$ Vid läsningen av dessa böcker och debattinlägg framgår det tydligt att bildningsbegreppet innehåller flera spänningar och paradoxer. Att åstadkomma någon enighet om hur begreppet skall definieras, vilken roll det har haft eller bör spela i framtiden är vare sig möjligt eller önskvärt. En av de många brytningarna återfinns i förståelsen av bildning som en individuell strävan efter att uppnå något som inte låter sig bestämmas i förväg samtidigt som resultatet av denna strävan alltid blir föremål för sociala och kulturella omdömen om huruvida individen verkligen är "bildad” eller inte. Bildning pekar mot olika former av kunskap och lärdom som samlats ihop under lång tid. Ibland ses dess tillgodogörande som besläktat med ett kanoniserat kulturarv eller kanske ännu oftare som ett tecken på kunskap om, och anslutning till, detta kulturarv. ${ }^{16}$ Arv innebär att något överlåts, lämnas eller förs vidare till efterkommande eller efterföljande som i sin tur förväntas förvalta och bevara och sedan i sin tur föra detta arv vidare. Talet om arv implicerar alltså att något förs vidare i en obruten kedja där de väsentliga egenskaperna förblir oförändrade. ${ }^{17}$

Trots de tendenser till optimism när det gäller bildningens framtid som förmärkts i de senaste årens diskussioner kan vi inte utesluta att det kan finnas en form av logik i att bildningen har förlorat $\mathrm{i}$ inflytande. Kanske är det relativt sett krympande intresset för bildning ett uttryck för att allt fler av dess funktioner av t ex identitetsskapande, klassoch statusmarkörer eller kollektiv bekräftelse kan tillgodoses på andra håll i samhället? Försiggår t ex dessa processer allt mer via nya former av medier, via reklam, musik, sport, egenterapeutiska kurser etcetera - områden och sfärer som inte tidigare hänförts till bildning? Förmedlas kanske vår förståelse av bildningen och kulturarvet någon annanstans än via de traditionella kanalerna?

\section{II}

Det är ingen tvekan om att förutsättningarna för bildningen har förändrats genom den tilltagande ekonomiska, politiska och kulturella globaliseringen och den samtidiga utvecklingen inom informationsteknologin. Andra viktiga tendenser som kan framhållas är en ny form av individualism, konsumismens växande betydelse och en minskande respekt för auktoriteter. Kunskap har blivit en allt viktigare vara samtidigt som naturvetenskap, teknik och medicin, dvs. per definition nyttiga och lönsamma vetenskaper, kommit mer i förgrunden medan humaniora och samhällsvetenskap relativt sett halkar efter. ${ }^{18}$ Även utvecklingen av den högre utbildningen till en massutbildning påverkar 13 Gustavsson 2012.

14 Gustavsson 2007; Gustavsson 2009; Burman \& Sundgren 2010; Burman \& Sundgren 2012.

15 Burman \& Sundgren 2010.

16 För en diskussion kring kulturarvets betydelse, se t ex Aronsson 2005; Alzén \& Aronsson 2006.

17 Se t ex Ruin 2007, s 49ff.

18 Ekström \& Sörlin 2011; Forser \& Kahlsson 2012. 
självfallet villkoren för kunskapsförmedlingen. Listan skulle kunna göras längre men kanske i synnerhet faktorer som tendensen att kunskap i allt högre grad betraktas som en vara, massutbildningens framväxt och det bristande intresset för humaniora hos politiker och näringsliv har betydelse för diskussionen om bildningens villkor. Samtidigt bör det dock betonas att det är frågan om tendenser och gradvisa förändringar vilka gör sig gällande med varierande styrka på olika sätt i olika sammanhang.

Ändå ifrågasätter nog få idag huvuddragen i denna beskrivning. Den viktiga frågan blir emellertid vilka slutsatser vi ska dra av de förändringar som skett. Det är angeläget att diskutera vilka krafter som ligger bakom dylika förändringar, hur dessa hänger ihop och, framför allt, vad dessa förändringar innebär för vår tid och i detta fall, för möjligheterna att eventuellt formulera ett nytt bildningsprojekt. De förändringar som nämndes ovan spelar idag stor roll för formandet av våra erfarenhetsvärldar, framför allt kanske hos ungdomar. Det är heller ingen tvekan om att ett växande inflytande och en ökande medvetenhet om andra kulturmönster har förändrat hur vi ser på vårt samhälle liksom på världen i stort.

Det finns på sina håll en utpräglad kritik mot modernitetens hierarkiska kultur- och bildningssyn där "finkultur" uppfattats stå mot "folklig" kultur, smak mot smaklöshet, dålig kultur mot bra kultur. I dag framhålls också ofta hur kulturer är flytande, ständigt föränderliga meningsskapande konfigurationer vilka till stor del är självrefererande och inte kan relateras och värderas i förhållande till något utanför sig själva. Vidare finns en betoning på att kultur är ett resultat av ett aktivt meningsskapande och på så sätt är en dynamisk storhet som hela tiden genomgår mutationer. Resultatet blir en aldrig tidigare skådad kultursynkretism där impulser från olika håll i världen blandas med lokala och regionala företeelser. Det har då också vuxit fram en hållning där kultur fungerar som ett redskap i en kamp om inflytande liksom för motstånd mot auktoriteter och etablerade strukturer, framför allt från olika ungdomsgrupper sida. Medan moderniteten var massamhällets epok, ser allt fler idag sin tillvaro som ett individuellt projekt, som något att förverkliga och där utvecklingen av "jaget” eller "självet" fått en helt annan tyngd än tidigare. Detta kan beskrivas som ett känslotillstånd där kraven på att skaffa sig en identitet - att bli och vara "någon" - i en svåröverskådlig värld kan upplevas som mycket krävande och där många människor, särskilt unga, kan sägas experimentera med sin egen subjektivitet och leta och söka sig fram i tillvaron.

Människors identitetssökande går också i andra riktningar än tidigare genom att man identifierar sig allt mindre med de gamla kollektiven och gemenskaperna samtidigt som de nya sociala och kulturella former som framträder är annorlunda och mer föränderliga. Detta kan för många vara en tung börda att bära inte minst då de reella socioekonomiska villkoren för många är starkt begränsa(n)de. Den sjunkande tilltron till auktoriteter och gamla svar har fört med sig vad som kan betraktats som kristendenser på en rad områden, inte minst legitimitetsproblem för de gamla ideologierna och för de politiska systemens företrädare, men även i vissa fall för den kunskap som vetenskapen producerar. Till dessa kulturella och sociala förändringar kommer en annan som indirekt påverkat 
villkoren för bildningen nämligen en växande relativism, både värdemässigt och kunskapsteoretiskt. Detta påverkar också indirekt bildningsfrågan då den värdemässiga aspekten länge, $\mathrm{t}$ ex i form av historieundervisningen och dess bindning till nationalstaten eller i form av inlärningen av en nationell litterär kanon som utgjorde en grundsten för bildningen. En given fråga har nu länge varit hur ungdomar och invandrar- och flyktinggrupper kan göras delaktiga av, eller ges möjligheter att själva skapa sig en form av bildning. Hur kan unga för att inte tala om olika etniska minoriteters erfarenheter bli en del av detta projekt? I förlängningen blir frågan om det längre är möjligt - och meningsfullt - att tala om bildning, kulturarv och historia i termer av något gemensamt?

Kan dagens och framtidens diskussion om bildning och kulturarv appellera till, och få en resonansbotten i gemensamma mänskliga erfarenheter? Är "det gemensamma” i ett samhälle ett tillräckligt starkt kitt för att vara en grund för bildningen idag? Vad som kan sägas är att bildningen måste ta en form som ger människor möjligheter att "känna igen sig” i. Det handlar inte bara om kunskapsinhämtande som en intellektuell aktivitet där man får sig till livs och bearbetar ett speciellt stoff och olika problem, det måste ses som en ständig, kontinuerlig process där vardagserfarenheter, dvs. det liv man lever i vid bemärkelse, spelar en grundläggande roll.

III

Bildning har tenderat att handla om kulturspecifika områden som språk, litteratur, konst och historia medan vad som betraktats som kulturellt neutrala områden som naturvetenskap, teknik och medicin fallit utanför. ${ }^{19}$ Denna klyvning har delvis sin grund i den akademiska världens uppdelning mellan olika områden men har, både organisatoriskt och finansiellt, också byggts in i en offentlig sektorisering där de förstnämnda områdena bestås jämförelsevis små resurser i jämförelse med de senare. Kanske finns det idag ändå tecken på framväxten av en ökad medvetenhet om att de olika områdena måste närma sig varandra, inte minst för att hantera globala utmaningar som klimatfrågan och befolkningsökningen. ${ }^{20}$ Gränserna mellan de olika områdena har emellertid också ifrågasatts på teoretiska grunder. Feminister och postinfluerade teoretiker har t ex hävdat att matematiken och fysiken, vilka kan ses som idealtyper för kulturellt neutrala ämnen med universella begreppssystem och förklaringsmodeller, också är impregnerade av manliga och eurocentristiska normer, vilket naturligtvis kan sägas om en stor del av den klassiska bildningen generellt.

En följd av den växande insikten om bildningens relativa och föränderliga karaktär är att dess kunskapsrealistiska underbyggnad har ifrågasatts. Det har hävdats att vi måste inse att det inte är möjligt att bygga bildning och kulturarv på någon "sann”, "objektiv" och en gång för alla given kunskap - åtminstone inte när det handlar om humaniora och samhällsvetenskap. Dagens och framtidens diskussion i dessa frågor kan inte utgå från den moderna epokens vetenskapsideal. I en mening kan vi bara anpassa oss till de förändrade förutsättningarna. På samma gång som moderniteten en gång bröt fram med

19 Se t ex Snow 1961.

20 Se t ex Myrdal 2009; Ekström \& Sörlin 2012. 
oemotståndlig kraft och, på gott och ont, förändrade hela vår värld har också postmoderniteten gjort det. Samtidigt kan människors anpassningsutrymme idag ses som större än det någonsin varit under modernitetens regel- och byråkratistyrda besluts- och organisationsformer.

Oavsett hur vi benämner den epok vi befinner oss i tror jag att vi kan säga att den reflektion som bör bli resultatet av insikten om de senaste decenniernas enorma förändringar måste inbegripa ett försök att hantera insikten om modernitetens begränsningar och därmed att lära sig leva i en pluralistisk värld som för med sig ambivalens, oklarheter och osäkerheter men också många möjligheter som saknades i moderniteten. Detta innebär att leva i ett "osäkerhetstillstånd" där nuet och framtiden - på gott och ont - är öppen, osäker och till synes utan klar färdriktning, trots vad politiker och ekonomer ibland vill få oss att tro. I en sen- eller postmodern värld där begrepp som individualitet och frihet (att välja) är högsta värden förskjuts bildningsbegreppet bort från sin förbindelse med kollektivt föreställda gemenskaper. Idag har det klassiska bildningsbegreppet överflyglats inte i första hand för att det, som tidigare decenniers vänsterkritiker framhöll, skulle stå för och legitimera en konservativ och orättvis (borgerlig) samhällsordning utan för sin universalisering av västerländska och patriarkala värden, för sin kunskapsteoretiskt naiva syn på sanning och makt och för sin likaledes naiva idealism.

Dessa insikter, nedslående eller inte, innebär emellertid inte att diskussionen kring bildning och kulturarv minskar i betydelse - jag skulle ville hävda att det faktiskt är tvärtom. Jag menar att en anledning till att bildningen under de senaste åren tilldragit sig ett ökat intresse är en bekräftelse på genomslaget för de stora samhällsförändringar som skisserades ovan. I det sen- eller postmoderna samhället kan man - till skillnad från vad som ofta var fallet i industrisamhällets sista decennier - finna både ett erkännande och ett bejakande av bildningens betydelse. Den moderna epokens rationalitets- och nyttotänkande ledde tillsammans med den dominerande framstegstanken till en instrumentell kunskapssyn där frågor som rörde bildning och kulturarv hade mycket svårt att göra sig gällande medan den epok vi nu lever i kan ses som uppvärdering av det förflutna i förhållande till nuet. Därför uttrycker den också en kritik mot modernitetens tendens att tillskriva nuet överhöghet över det förflutna. I en tid med snabba omvärldsförändringar och där många människor upplever en vilsenhet och otrygghet behövs mer än någonsin en reflexiv hållning till samhället och oss själva. Här kan ett vitaliserat bildningsbegrepp spela en viktig roll.

\section{IV}

Om vi så vänder oss mot Foucault så kan han, som antyddes ovan, naturligtvis framstå som en tänkare som ifrågasätter hela det moderna bildningsprojektet. Jag menar dock att det finns ett annat sätt att läsa och förstå Foucault som gör hans tänkande relevant för en samtida bildningsdiskussion. För att komma hit ska vi gå vägen via en diskussion och rekapitulering av några centrala inslag i Foucaults tänkande för att så småningom åter närma oss bildningsfrågan från en litet annat håll. Samtidigt kräver en sådan operation 
en utveckling och delvis omformulering av bildningsbegreppet där vi måste ifrågasätta vissa av de konnotationer som det länge har omgetts av: (i) dess tendens att se värdet av kunskap för dess egen skull, (ii) dess tendens att se bildning som en på förhand definierad kunskap (kanon), (iii) dess tendens att koppla samman bildning med en viss (god) etik eller moral och (iv) dess tendens att betona det nationellas, alternativt det västerländska kulturarvets försteg.

Sedan länge har den dominerande uppfattningen om Foucault varit att han var en tänkare för vilken olika former av makt stod i centrum, vanligtvis i kombination med ett framhållande av att denna makt inte kan skiljas från kunskap. Denna förbindelse blir naturligtvis väsentlig i varje diskussion kring den bildningen då denna är en form av kunskap. Låt oss därför börja med att notera att kunskap för Foucault inte har något värde i sig. Kunskapen är intimt förbunden med makt men inte, som i det klassiska upplysnings- och bildningstänkandet, genom att den ger oss makt över våra egna liv. Foucault menar att relationen är mer komplicerad än så. För det första är kunskap inte något som så att säga finns någonstans att hämta och därmed bli ägare av. Detta skulle i så fall implicera att kunskapen är skild från makten vilket Foucault menar är en missuppfattning. Kunskap är för Foucault alltid sammantvinnad med makt på ett sätt som gör att det ena kan sägas förutsätta det andra. För det andra är kunskap alltid konkret och relaterad till olika situationer. Foucault ser inte denna som något abstrakt utan som något som sätter sig på och tränger in i våra kroppar, handlingar, attityder och gester, kort sagt in i våra dagliga liv. Kunskap är med andra ord något som "sker” i de otaliga relationer som det mänskliga samhället består av. Den befinner sig därmed aldrig utanför makten och kan följaktligen inte heller förstås utan att den senare tas med i beräkningen. Kunskap är ett redskap, något att använda i det intellektuella arbetet där varje form av kanontänkande, liksom varje försök att föreskriva innehållsliga kriterier och inskränkningar är en form av "polisverksamhet”.

Samtidigt måste Foucaults makt-och kunskapsbegrepp ses i förhållande till friheten vilket innebär att utgångspunkten bör tas i en läsning av Foucault som en tänkare för vilken denna stod i centrum. Individen är, för Foucault, inget annat än en produkt av olika makteffekter och friheten handlar om att förändras i den riktning vi vill, vilket förutsätter att vi förstår att vi är mycket friare än vi tror. Det är dock även viktigt att inse att detta inte innebär att det finns något förutbestämt att sträva efter. Strävandet efter frihet är därför, hos Foucault, alltid ett slags prövande och experimenterande. ${ }^{21}$ Därför skulle det strida emot grunderna i Foucaults projekt att föreskriva hur detta frihetens tillstånd ser ut.

\section{V}

Nyckeln för ett foucaultianskt sätt att angripa frågan om bildning blir att se och förstå dess roll i subjektblivandet. Härmed blir bildningen inte främst ett stoff eller en kompetens utan en slags hållning. Foucault talade om en "gränsattityd", en attityd som hela tiden sökte möjligheten att inte längre vara, göra eller tänka vad vi är utan vad vi kan bli, 21 May 2011, s 80. 
en experimentell attityd som testas mot samtidens verklighet i form av dess maktstrukturer och maktrelationer för att finna punkter där förändring är möjlig. Foucault startade hela tiden sitt frågande i nuet, i vad som betyder något för oss här och nu. Således handlar bildningen i djupare mening mer om samtidsförståelse och subjektsformering än om inlärning av en viss kunskapsmassa, språklig kompetens eller anammande av en speciell metod för kunskapsinhämtning.

Genom insikten att nuet har skapats på ett visst sätt följer också att det kunde sett ut och konstruerats på ett annat, något som också ger en utgångspunkt för handlande, för aktivism. Detta var något som stod i fokus för hela Foucaults projekt. Det innebar att studera hur subjekten ser på sig själva, analyserar, bedömer, tolkar och förstår sig själva, med andra ord hur subjekten uppfattar sig inom en möjlig kunskapsordning. Foucault betonar hela tiden hur vi förstår oss själva historiskt genom de föränderliga sanningar om oss som dominerar vid varje specifik historisk tidpunkt och inte via någon universell matris för vad människan är. Samtidigt menar han att de processer det här rör sig om historiskt har förskjutits och delvis ändrat karaktär från en betoning på extern disciplinering (i t ex fängelser, mentalsjukhus, militärbaracker och skolor) mot en betoning på intern disciplinering och självsubjektivering. Förstått i relation till bildningen kan denna förändring ses i förskjutningen från 1800-talets språkpluggande, utantillinlärning och läsning av en kanon av "goda” och karaktärsdanande skrifter till vår tids "fria” bildning där det ständigt står en strid om såväl dess form som innehåll. Att bildningen och kulturarvet har med maktrelationer att göra innebär naturligtvis också att det förs en kamp omkring detta. Det är så att säga "up for grabs”, något man lägger beslag på, usurperar och skär ut vissa bitar ur för att använda. Det är dock viktigt att påminna om att kamp för Foucault i princip aldrig är en våldsam kamp - han är i själva verket anmärkningsvärt ointresserad av våld - så ointresserad att han i princip definierar ut våld från sitt maktbegrepp.

Foucault kom gradvis att allt mer intressera sig för vad han kallade "den individualiserande maktens problem". Han framhöll att detta innebar att individen separerades från andra individer och att banden mellan individer försvagades samtidigt som det som gjorde oss till individer underminerades. Den individualiserande makten verkade, enligt Foucault, både uppdelande mellan individer och inom individen där såväl vetenskapliga, administrativa som ekonomiska makt/kunskapspraktiker verkar och gör oss till de subjekt vi blir. En annan viktig aspekt är att Foucault betonade självskapandet som ett arbete, något som kräver ansträngning och koncentration men som också bygger vidare på tidigare tillägnade kunskaper och färdigheter. Så tar sig också subjektets förhållande till bildningen formen av ett arbete. Allt arbete är en fysisk aktivitet, antingen denna försiggår med musklerna, sinnesorganen eller intellektet. Detta innebär också att bildning inte enbart, eller ens till största delen är teoretisk, utan praktisk. Denna praktik läsning, skrivande, lyssnande, övning etc. - är en del i formeringen av subjektet. Denna självtransformering är i sin tur en ständigt pågående process som man aktivt måste underhålla och arbeta med. Därför kan heller aldrig bildningen, oavsett hur vi definierar dess innehåll, funktion eller syfte, bli en del av subjektets självkonstituering utan denna 
ansträngning. Bildningen får därför inte förväxlas med inlärningsformer eller aktiviteter där leken, lusten och nöjet är det primära. Detta blir tydligare om man förstår att bildningen utifrån ett foucaultinspirerat synsätt mer handlar om tänkande än om inlärning och kunskap i sig - att tänka är i djupare mening alltid mödosamt.

Mot slutet av hans liv försköts fokus för Foucault i hög grad bort från explicita maktresonemang, dels genom att han allt mer vände blicken inåt mot det egna subjektet, mot, som han kom att kalla det, "omsorgen om sig själv”, dels mot studiet av antikens och den tidiga kristendomens förhållningssätt till sexualiteten och den egna kroppen. Foucaults arbete under de sista åren blev därmed på samma gång ett utforskande av den västerländska kulturens rötter och en strävan efter att förstå hur subjektet etablerade ett förhållande till sig själv som gjorde det möjligt att överskrida de samhälleligt producerade subjektsformer som uttrycker den enskildes inordning i makt- och dominansrelationer. Det framstod som nödvändigt att nå fram till insikt om hur och i vilken grad det var möjligt att tänka annorlunda för att kunna bryta sig ut ur det bildliga fängelse som utgjordes av modernitetens tankesystem och praktiker. Detta kan, menar jag, förstås i termer av bildningsarbete.

I antikens omsorg om sig själv och i den ökande betoningen på självstyrning fann Foucault en väg för frigörande av i alla fall en del av de mentala bojor människan är fjättrad av. Därmed kan man säga att hans filosofiska livsprojekt utmynnade i arbetet med att finna och utforska vägarna för att lossa dessa bojor - inte i att visa att vi var instängda och fångade i maktens garn. Det gällde, menade Foucault, att etablera makt över sig själv på ett sätt som minskade strävandena efter makt och dominans över andra. Därför är omsorgen om sig själv inte en narcissistisk självbespegling utan grunden för en etik ett förhållande till andra - den är därmed också utgångspunkten för en omsorg om andra, ett sätt att förhålla sig till andra människor på ett sätt som kontrollerar och begränsar makten och minimerar den samhälleliga produktionen av maktrelationer. I stoikernas efterföljd talar Foucault om att den som inte idkar omsorg om sig själv inte heller har kontroll över sina begär, passioner och drifter vilket leder till att han inte heller kan tygla sina strävanden efter makt och dominans över andra. Här kan, som jag ser det, bildningen som kunskapsform och praktik få en framträdande plats. Men det gäller att finna en ”stil” eller teknik som kan fungera som ett möjligt förhållningssätt för detta (bildnings) arbete med sig själv. En anledning till Foucaults intresse för antiken var att han menade att situationen under denna period delvis påminde om situationen idag. Också idag har vi genom de snabba och djupgående samhällsförändringar som skett under de senaste decennierna svårt att finna en grund för våra förhållningssätt.

\section{VI}

Ett Foucaultinspirerat tänkande formulerar om den (minst) tvåhundraåriga frågan om vad bildning är till en fråga om hur bildning verkar och fungerar. Ett sätt att söka svar på denna fråga vore att i hans efterföljd skriva en sorts "bildningens genealogi”. En sådan historieskrivning skulle måhända betona bildningens karaktär av diskursiv praktik 
där tillfälligheter, strider och motsättningar är de drivande krafterna och där det snarare handlar om vad som uteslutits och trängts undan än om kontinuiteter, idépåverkan, stora män och om det intellektuella arvet. Det skulle då framträda hur bildning i olika sammanhang är något som konstruerats och iscensatts utifrån politiska, ideologiska, estetiska, etiska och lingvistiska utgångspunkter. Detta gäller all bildning, oavsett vad den själv beskriver sig som. Att bildningen är något konstruerat innebär dock inte att den är godtycklig och kan se ut hur som helst - också konstruktörer arbetar utifrån ritningar, traditioner, personliga erfarenheter och målsättningar - däremot innebär erkännandet av bildningens konstruerade karaktär att vi också måste rikta uppmärksamheten mot de mekanismer som utgör dess konstruktionsprocesser. Samtidigt måste det alltid hållas i minnet att bildningen bygger på en asymmetrisk opposition mellan dem som iscensätter en bildningsrepertoar och dem som saknar tillgång till denna. ${ }^{22}$

Jag menar dock att ett mer intressant och fruktbart sätt att låta Foucaults tänkande konfronteras med bildningsdiskussionen är via en förståelse av bildning i termer av den subjektiveringsprocess som beskrivs ovan - en praktik ytterst syftande till skapandet av sig själv som individ. Härigenom kan bildning också förstås som en motståndspraktik. Så har bildningen tidigare i historien också kunnat framstå för många från arbetarklassen och den lägre medelklassen som via skolor, bildningsverksamheter och så småningom kanske också högre utbildning kunde tillgodogöra sig ett betydande intellektuellt kapital. Utan att gå in på en diskussion kring det svenska utbildningsväsendet är det, skulle jag tro, relativt okontroversiellt att sätta frågetecken för om dessa förutsättningar råder inom utbildningssystemet idag. En aspekt av denna problematik är att det för många inom högskolevärlden inte är svårt att se behovet av ett motstånd både på individuell och kollektiv nivå mot många av de tendenser till ökad politisk och byråkratisk styrning och marknadstänkande som kan iakttas inom den högre utbildningen och som medfört minskad autonomi. ${ }^{23}$

I bildningens praktik produceras de betingelser och möjligheter som är nödvändiga för strävandet mot frihet. Friheten möjliggörs därmed av kunskapen och makten och föds ur (det nödvändiga) motståndet, ur vägran att underkasta sig. På så sätt blir motståndet inte en negativ handling utan en ständigt pågående kreativ process. Bildning blir då på samma gång ett verktyg att använda i självstyrningen och i skapandet av sig själv som subjekt, inte ett tillstånd av frihet, något det ofta framställts som inom bildningstradi-

22 Se t ex Kaveh 2012.

23 Donald Broady har hypotetiskt framhållit att bildningen blir fruktbärande enbart i sammanhang där tillräcklig autonomi råder. De epoker och sammanhang Broady framhåller som exempel på sådana (lyckliga?) ögonblick i historien - Preussen efter sekelskiftet 1800 och USA:s östkust hundra år senare - ger dock anledning till att funderingar om autonomi i denna bemärkelse kan återskapas i den sen- eller postmoderna värld vi nu lever i. Av Broadys beskrivning av de förutsättningar som då rådde framgår att autonomin var intimt förknippad med en klassmässig och ideologisk samsyn av ett slag som är betydligt svårare att tänka sig idag. Vidare menar Broady att det är i sociala sammanhang som redan besitter ett tillräckligt mått av autonomi som bildningsidealen får fäste. Autonomin måste alltså vara etablerad redan på förhand. Om Broadys hypotes om kopplingen mellan bildning och autonomi är riktig tycks de framtida möjligheterna för den klassiska bildningen vara dystra. I relativt få sammanhang i vårt allt mer multietniska och mångkulturella samhälle återfinns dessa förutsättningar. Se Broady 2012. 
tionen. Det är vidare nödvändigt att återigen understryka att bildningen kommer till uttryck i konkreta relationer och situationer. Det gäller alltså att göra bruk av bildningen. Foucault betonar att detta bygger på självdisciplin och självreflektion, något som 1800-talets borgerskap förvisso förstod men som många idag tycks ha glömt bort. För Foucault innebär detta mer konkret att individen använder sig av olika självtekniker. Därmed betonas också bildningens "verktygsartade” karaktär - på samma sätt som Foucault själv framhöll att hans begrepp kunde ses som verktygslådor som andra kunde låna ur kan bildning ses som något som används, något som människorna ska kunna ha med sig som ett verktyg i sina liv. Däremot avvisas den (oftast implicita) utgångspunkten att sökandet efter, och förmedlingen av bildningen framskrider progressivt mot önskvärda mål samtidigt som det understryks att det är nödvändigt att ge upp föreställningen om bildningen som en enda. Det måste erkännas att bildning alltid är för någon, att den alltid har olika syften och att varje försök att beskriva den bara är en av flera möjliga berättelser. Vi måste erkänna och öppet diskutera vad eller vilka krafter som bestämmer de problem som upplevs som angelägna vid ett visst tillfälle och vad som vid varje konkret tidpunkt hålls för att vara bildning. Om bildningen med andra ord skall kunna fungera som ett teoretiskt och praktiskt instrument för social förändring via transformeringen av individer - som den t ex gjorde under framväxten av det borgerliga samhället under 1800-talet eller för många inom det tidiga 1900-talets arbetarrörelse - måste alltså ett omtänkande ske.

I den mån bildning spelar en roll i det tjugoförsta århundradet äger detta rum i en ny kontext, en kontext där som framgått förutsättningarna för kunskap och kunskapsproduktion har förändrats, en kontext där kraven på den enskilde att själv kunna orientera sig i myllret av information är en förutsättning för kunskap och där den enskilde själv måste skaffa sig kompetens och kapacitet för att ur det enorma och oöverskådliga informationsflödet kunna forma användbara redskap i sitt subjektskapande. Genom kommunikationsteknikens utveckling och ökande möjligheter att resa och arbeta i andra länder, genom mediernas och kapitalets globalisering och som en följd av växande flykting- och immigrationsströmmar från mer avlägsna länder och kulturer har vi till stor del andra referenspunkter än i går. En fråga bland många blir därför hur bildningen och kulturarvet kan relateras till en ny "medvetandehorisont" vad det gäller förbindelsen mellan historieuppfattning, samtid och förväntningar om på denna framtid. Det blir mindre viktigt att samla och reproducera kunskap medan förmågan att använda den på nya sätt i nya sammanhang ökar i betydelse.

Genom att betona bildningens centrala plats i subjektskapandet framträder också dess produktiva potential tydligare. Bildning som subjektskapande innehåller emellertid även en kritisk granskning av sig själv liksom ett bejakande av kontingensen och pluraliteten i det sen- eller postmoderna samhället. Detta ger möjligheter att ställa nya frågor om politik, etik och rättvisa som kan bli en del i vårt självskapande. ${ }^{24}$ Det är alltså en slags resurs som gör att vi inte är helt utelämnade åt maktens verkningar utan, under vissa

24 Taylor 2011, s 178f. 
förutsättningar, kan skapa nya subjektsformer. Kritiken, dvs. granskandet och reflekterandet över samhället och oss själva, förutsätter dock också nyfikenhet och en ständig opposition mot det som tas för givet och framstår som sanning. ${ }^{25}$ Den handlar inte om att skaffa sig kunskap i substantiell mening utan om subjektets förhållningssätt till de begränsningar som olika sanningar eller "sanningsregimer" utgör för subjektet. ${ }^{26}$ Det sagda innebär att bildningens formella sida måste tonas ner och processen, tänkandet, reflektionen, sättas i centrum och dess kritiska, om man så vill, kantianska sida betonas.

Genom Foucaults "återläsning” av Kant i slutet av sitt liv skapades en förbindelse mellan den förstnämndes konceptualisering av subjektskapandet och den senare som inspiratör till den klassiska bildningstraditionen. ${ }^{27}$ Detta genom att Foucault i ett par uppmärksammade sena texter anknöt till upplysningen och dess kantianska arv vars viktigaste insikt han framför allt såg i konstitueringen av ett autonomt subjekt i ett konkret nu. ${ }^{28}$ Upplysningen skulle enligt Foucault förstås inte som en epok, ideologi eller tankevärld utan som en "attityd” som på samma gång innebär en problematisering av människans relation till sin samtid, hennes plats i historien och konstitueringen av sig själv som autonomt subjekt. ${ }^{29}$ Foucault kan därmed sägas vidareutveckla och radikalisera Kants tanke om att människan genom att träda ut ur sin "självförvållade omyndighet" kan frigöra sig från traditionens och oförnuftets bojor till att handla om att få tillgång till ett verktyg för en ständig "kritik av oss själva”.

Med Foucault kan vi än starkare betona bildningens karaktär av en självskapande och ständigt pågående process. Bildning som en slags livshållning kan bli ett inslag i våra försök att skapa nya former av subjektivitet, i ständig kamp att undgå statens, marknadens eller mediernas styrande och normaliserande verkningar. Genom att diskutera bildningen med hjälp av några av de många tankar om människan och hennes villkor som Michel Foucault producerade har jag velat ge en litet annorlunda vinkling till denna pågående och viktiga diskussion. Det kreativa självskapandet är dock bara den ena sidan av bildningen där den andra är de vid varje tidpunkt dominerande tankarna - diskurserna - om människa, samhälle och framtid men också beträffande hur själva bildningen skall gå till. I diskussionen har det också varnats för att denna självskapande sida av bildningen skulle riskera att gå för långt, i varje fall om den ges allt för fritt spelrum allt för tidigt i skolan. ${ }^{30}$ Må så vara när det gäller ännu unga och formbara individer men när det gäller vuxna människor och deras livslånga bildningsarbete skulle förmodligen Foucault ha sagt att vi nog inte behöver oroa oss för att människors frihet blir för stor. Maktens normaliserande och disciplinerande verkningar kommer alltid att

\footnotetext{
25 Taylor 2011, s $182 \mathrm{ff}$.

26 Lemke 2012, 62f.

27 Foucault ägnade i sin ungdom betydande intresse åt Kant. Bland annat utgav han en introduktion till dennes antropologi som en del av sin doktorsexamen. Därefter avlägsnade han sig dock under en lång period från Kants tänkande innan han mot slutet av sitt liv återkom till vissa sidor hos denne. Se Foucault 2008c.
}

28 Foucault 1991; Foucault 2008a.

29 Foucault 1991, s 39f.

30 Broady 2012, s 303f. 
finnas där som något att förhålla sig till och göra motstånd emot. ${ }^{31}$ I detta sammanhang är bildningsarbetet idag mer oundgängligt än någonsin tidigare.

\section{Referenser}

Alzén, Annika \& Aronsson, Peter (red.), Demokratiskt kulturarv? Nationella institutioner, universella värden, lokala praktiker. Tema kultur och samhälle, Linköpings universitet 2006.

Aronsson, Peter (red.), Kulturarvets gränser. Komparativa perspektiv. Göteborg: Arkipelag 2005.

Björck, Henrik, Folkhemsbyggare. Stockholm: Atlantis 2008.

Broady, Donald, 'Bildningstankens krumbukter. Några blad ur historien från 1970-tal till 2010-tal', i Burman, Anders \& Per Sundgren (red.), Svenska bildningstraditioner. Göteborg: Daidalos 2012.

Burman, Anders \& Sundgren, Per (red.), Bildning. Texter från Esaias Tegnér till Sven-Eric Liedman. Göteborg: Daidalos 2010.

Burman, Anders \& Per Sundgren (red.), Svenska bildningstraditioner. Göteborg: Daidalos 2012.

Ekström, Anders \& Sörlin, Sverker, Alltings mått. Humanistisk kunskap i framtidens samhälle. Stockholm: Norstedts 2012.

Forser, Tomas \& Kahlson, Thomas (red.), Till vilken nytta? En bok om humanioras möjligheter. Göteborg: Daidalos 2013.

Foucault, Michel, 'What is Enlightenment?', i Paul Rabinow (red.), The Foucault Reader. An Introduction to Foucault's Thought. London and New York: Penguin 1991.

-, Sexualitetens historia. Band 2, Njutningarnas bruk. Göteborg: Daidalos 2002b.

-, 'Vad är upplysning?', i Michel Foucault, Diskursernas kamp. Texter i urval av Thomas Götselius \& Ulf Olsson. Stockholm/Stehag: Brutus Östlings Bokförlag Symposion 2008a.

-, 'Självteknologier', i Michel Foucault, Diskursernas kamp. Texter i urval av Thomas Götselius \& Ulf Olsson. Stockholm/Stehag: Brutus Östlings Bokförlag Symposion 2008b.

-, Introduction to Kant's Anthropology. Los Angeles: Semiotext(e) 2008.

Fölster, Stefan, Kreicsbergs, Johan \& Sahlin, Malin, Konsten att strula till ett liv. Om ungdomars irrvägar mellan skola och arbete. Svenskt Näringsliv 2011.

Gustavsson, Bernt (red.), Bildningens förvandlingar. Göteborg: Daidalos 2007.

Gustavsson, Bernt, 'Bildningens traditioner i transformation', i Burman, Anders \& Per Sundgren (red.), Svenska bildningstraditioner. Göteborg: Daidalos 2012.

Jonsson, Stefan, 'Apans bildningsresa. Europeiska bildningsidéer och postkolonial teori', i Gustavsson, Bernt (red.), Bildningens förvandlingar. Göteborg: Daidalos 2007.

Kaveh, Shamal, 'Bildningsbegreppets ontologiska kluvenhet', i Burman, Anders \& Per

Sundgren (red.), Svenska bildningstraditioner. Göteborg: Daidalos 2012.

Lemke, Thomas, Foucault, Governmentality and Critique. Boulder: Paradigm Books 2012. May, Todd, 'Foucault's conception of freedom', i Dianna Taylor (red.), Michel Foucault: Key Concepts. Durham: Acumen 2011.

31 Jfr. McGushin 2011, s 140f. 
McBride, Kealy, Punishment and Political Order. Anna Arbour 2007.

McGushin, Edward, 'Foucaults theory and practice of subjectivity', i Dianna Taylor (red.), Michel Foucault: Key Concepts. Durham: Acumen 2011.

Myrdal, Janken, Spelets regler i vetenskapens hantverk. Om humanvetenskap och naturvetenskap. Stockholm: Natur \& Kultur 2009.

Niléhn, Lars H., Nyhumanism och medborgarfostran. Åsikter om läroverkets målsättning 1820-1880. Malmö: Gleerups 1975.

Nilsson, Roddy, Foucault - en introduktion. Malmö: Egalité 2008.

Nordin, Svante, Humaniora i Sverige. Framväxt - Guldålder - Kris. Stockholm: Atlantis 2008.

O’Farrell, Clare, Michel Foucault. London: Sage 2005.

Pickett, Brent, On the Use and Abuse of Foucault for Politics. Lanham: Lexington Books 2006.

Ruin, Hans, 'Frihetens hemlighet och bildningens uppgift', i Gustavsson, Bernt (red.), Bildningens förvandlingar. Göteborg: Daidalos 2007.

Said, Edward, Orientalism. Stockholm: Ordfront 1993.

Snow, C.P., De två kulturerna. Uppsala: Verdandi 1961.

Taylor, Dianna, 'Practices of the Self', i Dianna Taylor (red.), Michel Foucault: Key Concepts. Durham: Acumen 2011.

Uljens, Michael, Bildning och kritikens möjligheter, www.vasa.abo.fi/users/muljens/pdf/Bildning och_kritikens mojlighet_11_10_2007.pdf 